\title{
ANALISIS STRATIGRAFIKRONOLOGI HUNIAN SITUS LOYANG UJUNG KARANG, ACEH TENGAH
}

\author{
STRATIGRAPHYCAL ANALYSIS OF THE SETTLEMENT \\ CHRONOLOGY ON LOYANG UJUNG KARANG, CENTRAL ACEH
}

\author{
Taufiqurrahman Setiawan \\ Balai Arkeologi Medan \\ tokeeptheexplorer@gmail.com
}

\begin{abstract}
This paper tries to describe the chronolgy of settlement in Loyang Ujung Karang site by using stratigraphic data from excavation data in 2010, 2011, and 2012, to correlate it with the archaeological data, five human remains found from different burial systemand radiocarbon dating results.From the pottery, human remains, leaf casting and woven rattan found in this cave showed that cave was inhabited before $4400+120$ BP. This site was abandoned around $2590+120$ BP because there was a flood inside the cave during the rise of Lut Tawar Lake surface level.This site then reoccupied between $2590+120$ BP until $1900+100$ BP based on the burial remains. Further occupation could not be determinated because it is not analyzed yet. However, based on Ming's ceramicwas found, shows us that this cave was inhabited continually from $4280 \mathrm{BP}$ until $200 \mathrm{BP}$.
\end{abstract}

Keywords: Settlement, Stratigraphy, Chronology, Human remains

\begin{abstract}
ABSTRAK
Tulisan ini akan menganalisis kronologi hunian di Situs Loyang Ujung Karang dengan menggunakan analisis stratigrafi hasil ekskavasi tahun 2010, 2011, dan 2013, mengkorelasikannya dengan data temuan arkeologi berupa temuan lima temuan rangka manusia dalam posisi kubur yang berbeda-beda dan hasil pertanggalan radiokarbon. Penelitian ini menunjukkan bahwa situs tersebut telah dihuni sebelum $4400 \pm 120$ BP dengan bukti adanya fragmen gerabah, rangka manusia, absklat daun, dan anyaman rotan. Lokasi ini kemudian ditinggalkan sampai $2590 \pm 120$ BP disebabkan oleh gangguan alam, yakni tergenangnya permukaan gua akibat naiknya permukaan Danau Lut Tawar. Situs ini baru kemudian digunakan antara $2590 \pm 120$ BP hingga $1900 \pm 100$ BP dengan adanya bukti penguburan manusia. Pemanfaatan lokasi pada masa berikutnya belum didapatkan pertanggalan radiokarbonnya. Walaupun demikian, berdasarkan temuan fragmen keramik Dinasti Ming, menunjukkan bahwa gua tersebut telah dimanfaatkan berulang-ulang dari periode $4280 \mathrm{BP}$ hingga 200BP.
\end{abstract}

Kata kunci: Hunian, Stratigrafi, Kronologi, Rangka manusia 


\section{PENDAHULUAN}

Sebelum manusia menetap dan membangun bangunan tempat tinggal 퐂 $@$ seperti sekarang, mereka membutuhkan perlindungan terhadap cuaca dan gangguan binatang buas dan dekat dengan sumberdaya makanannya. Tempat tinggal tersebut dapat di lokasi baik terbuka maupun gua atau ceruk. Tentunya gua yang dipilih sebagai lokasi hunian harus mempunyai morfologi lantai yang dapat menampung seluruh anggota kelompoknya, lantai yang kering dan datar, serta memiliki sirkulasi udara dan pencahayaan yang baik. Lokasi tersebut berfungsi sebagai tempat tinggal, aktivitas, dan bahkan penguburan. Pemanfaatan gua untuk lokasi penguburan sangat menarik untuk diamati karena menunjukkan adanya manusia yang menghuni wilayah tersebut. Selain itu, data ini dapat mengungkap banyak aspek yang berkenaan dengan demografi pada masa prasejarah, seperti populasi, aspek sosial-budaya, genetika, dan proses migrasi penduduk.

Penelitian arkeologi di lokasi gua dilakukan karena data yang dihasilkan memberikan gambaran yang berfungsi untuk rekonstruksi baik sejarah maupun proses budaya mulai pada masa mesolitik atau masa berburu dan mengumpulkan makanan tingkat lanjut (Nurani 1995, 78). Selain itu, gua juga menyimpan data arkeologi setidaknya dari kala pleistosen akhir(sebelum 11.000 tahun yang lalu) hingga kala awal holosen. Beberapa data hasil penelitian gua dan ceruk hunian prasejarah yang pernah dilakukan di beberapa wilayah Indonesia telah banyak memberikan bukti tentang pola pemanfaatan ruang gua sebagai lokasi penguburan.

Bukti pemanfaatan gua sebagai lokasi hunian dan penguburan sejak masa prasejarah telah ditemukan oleh para arkeolog di sebagian besar wilayah Indonesia. Salah satu hunian terbaru ditemukan di Situs Loyang Ujung Karang dan empat rangka manusia di Loyang Mendale, Takengon, Kabupaten Aceh Tengah, Provinsi Aceh pada penelitian Balai Arkeologi Medan sejak tahun 2009 hingga 2012. Pada situs tersebut ditemukan temuan rangka manusia dalam posisi kubur yang berbeda-beda.

Beberapa hasil penelitian di Indonesia tentang sistem penguburan terlipat tersebut, antara lain di Song Keplek, Gua Braholo, Song Gentong, Gua Lawa, Ceruk Sodong, Gua Marjan (Simanjuntak 1998, 1-20). Berdasarkan pertanggalan radiokarbon yang telah dilakukan pada penelitian di Gua Braholo di Gunungsewu, Gunungkidul, Daerah Istimewa Yogyakarta telah menghasilkan data yang menyebut bahwa gua tersebut telah dihuni sejak $9150 \pm 390$ BP hingga 3050£100 BP. Pertanggalan tersebut berada satu konteks dengan keberadaan rangka manusia yang juga dikuburkan pada lokasi tersebut. Dari penelitian lain di Song Keplek ditemukan juga data temuan penguburan manusia dengan hasil pertanggalan radiokarbonnya adalah $7020+180$ BP (Simanjuntak 1998, 13; Simanjuntak 2002) Data tersebut berasal dari penelitian gua di wilayah Pulau Jawa. Penelitian sejenis di luar Pulau Jawa yang telah dilakukan adalah di Gua Tengkorak, Gua Kebobo (Sugiyanto 2009, 133-144), Gua Pawon (Yondri 2010, 1-10) dan Gua Harimau (Kompas 2010).Salah satu data terbaru berkenaan dengan hal tersebut adalah penemuan lima buah rangka manusia di Situs Loyang(Gua) Ujung Karang.

Sistem penguburan primer terlipat dengan posisi terlentang di dalam gua merupakan salah satu bagian dari budaya yang sering dijumpai di wilayah Asia Tenggara. Menurut Harry Widianto, sistem penguburan ini berasal dari daratan Asia Tenggara sekitar 10.000 tahun yang lalu yang menyebar ke arah selatan dan barat Nusantara yang kemudian menyebar ke timur ke Nusa Tenggara(Sugiyanto 2009, 133-144). Selain tradisi penguburan terlipat terlentang tersebut, kadang-kadang juga ditemukan sistem penguburan yang menempatkan blok-blok batu pada beberapa bagian-bagian tertentu seperti kepala, dada, dan pergelangan kaki. Fenomena penguburan tersebut juga 
ditemukan di Loyang Mendale. Namun blok-blok batu tersebut ditempatkan di atas tulang pinggul (pelvis) dan juga pada bagian kepala. Selain itu, si mati dikuburkan dengan kedua kakinya dilipat ke arah kiri (Wiradnyana dan Setiawan 2011, 64)

Di Asia Tenggara Daratan perlakuan-perlakuan terhadap mayat semacam itu banyak ditemukan pada situs-situs masa mesolitik yang dikaitkan dengan budaya Hoabinh. Selain itu, di situs Gua Cha, Kelantan, Malaysia yang merupakan situs Hoabinh berasal sekitar 10.000 sebelum Masehi, dijumpai rangka seorang pemuda yang dikubur terlipat, berbantal lempengan batu dan bagian tubuhnya ditindih dengan bongkahan batu tufa serta ditaburi oker merah. Di Niah, Malaysia ditemukan penguburan dalam posisi terlipat yang berasal dari masa berkisar 9.000 sebelum Masehi. Beberapa tulang yang ditemukan masih menyisakan bubuk oker. Bubuk oker juga ditemukan pada peralatan batu, lancipan tulang dan cangkang kerang yang merupakan bekal kubur. Di Gua Kepah, Pulau Penang, Malaysia juga ditemukan penguburan sekunder yang ditaburi dengan oker merah yang berasosiasi dengan peralatan Hoabinh serta di Gua Duyong, Pulau Palawan, Filipina Selatan ditemukan kerangka yang dikubur terlipat yang berasal dari masa sekitar 3.000 sebelum Masehi (Bellwood 2000, 245-325)

Sedikitnya data tentang kehidupan pada masa prasejarah di Sumatera bagian utara, terutama di wilayah pedalaman yang berada di punggung Pegunungan Bukit Barisan, mendorong perlunya penelitian di wilayah tersebut. Selama ini data yang ditemukan di wilayah ini hanya berada di wilayah pesisir timur, yaitu penelitian yang dilakukan di Situs Bukit Kerang(kjokkenmodinger) Pangkalan, Aceh Tamiang, Provinsi Aceh dan Situs Bukit Kerang Sukajadi, Langkat, Provinsi Sumatera Utara. Hasil dari penelitian tersebut memberikan gambaran akan penghunian wilayah ini mulai dari 12.000 tahun yang lalu. Pada lokasi tersebut telah ditemukan adanya data penghunian pada masa prasejarah berupa kapak batu Sumatera (Sumatralith) dan juga rangka manusia yang dimakamkan dengan sistem penguburan terlipat yang ditaburi dengan oker/hematit (Wiradnyana 2011, 100-107). Oleh karena itu, maka penelitian di wilayah pedalaman menjadi sangat penting untuk dilakukan dalam upaya mengisi bagian kosong tentang hunian prasejarah di Sumatera bagian utara. Selain itu, dengan mengkorelasikan data pertanggalan radiokarbon dengan analisis stratigrafi yang ditemukan pada masing-masing situs dapat memberikan informasi yang lebih tepat berkenaan dengan kronologi hunian suatu lokasi dan juga aspek lingkungannya.

Berdasarkan latar belakang yang telah dikemukan di atas, permasalahan dalam tulisan ini adalah bagaimana kronologi hunian di Situs Loyang Ujung Karang?

Tulisan ini bertujuan menggambarkan kronologi hunian di Situs Loyang Ujung Karang berdasarkan pengamatan pada stratigrafi tanah pada ekskavasi yang dikorelasikan dengan data pertanggalan radiokarbon dan rangka manusia yang ditemukan.

\section{METODE PENELITIAN}

Penelitian ini menggunakan analisis stratigrafi yang ditemukan pada kegiatan penelitian di gua-gua di Kabupaten Aceh Tengah pada tahun 2010, 2011, dan 2012. Metode analisis stratigrafi yang digunakan dalam tulisan ini adalah adaptasi metode Edward Harris (Harris Matriks). Beberapa kelemahannya tampak pada kurangnya catatan data stratigrafi secara horisontal serta tidak dilakukannya klasifikasi temuan arkeologi berdasarkan lapisan stratigrafi dan karena teknik ekskavasi dengan spit yang tidak memperhatikan lapisan stratigrafi sebagai aspek penandanya.

Stratigrafi adalah penafsiran lapisan horizontal pada tanah yang terdeposit pada sebuah situs dari waktu ke waktu. Dalam situs arkeologi, lapisan 
stratigrafi dapat terdiri dari berbagai bahan yang mungkin seluruhnya terdiri dari deposit alam seperti sedimen terakumulasi oleh air atau angin (natural I $($ transform), atau mungkin seluruhnya terdiri dari materi budaya yang tersusun dari hasil aktivitas budaya masa lalu (cultural transform), seperti lapisan kerang dalam bukit kerang atau bahan bangunan. Dalam hal ini stratigrafi pada situs juga dapat terdiri dari kombinasi material alam dan budaya. Penafsiran stratigrafi pada suatu situs merupakan salah satu komponen yang sangat penting untuk memahami sesuatu yang terjadi di sebuah situs arkeologi. Ini adalah titik awal untuk mengembangkan urutan waktu di situs tersebut dan menentukan usia relatif artefak dalam situs. Oleh karena itu, perlu pengkajian pada lapisan stratigrafi yang berbeda pada situs-situs arkeologi dan menafsirkannya untuk menciptakan kerangka kerja untuk kronologi relatif peninggalan budaya dalam situs (Balme dan Paterson 2006, 97-116).

Interpretasi stratigrafi untuk menyimpulkan kronologi situs ini didasari pada seperangkat prinsipprinsip yang merangkum implikasi dari proses pembentukan lapisan tersebut. Prinsip-prinsip stratigrafi yang digunakan oleh arkeolog mengadopsi metode dan teori yang dikembangkan oleh ilmuwan geologi. Namun, beberapa arkeolog berpandangan bahwa disiplin arkeologi memerlukan teori stratigrafi yang dapat diterapkan dalam penelitian arkeologi. Salah satunya dikemukan oleh Harris (1989) yang mengemukakan bahwa kontribusi manusia untuk pembentukan situs ini tidak seperti proses pembentukan situs alam, dan karena itu hukum geologi tidak dapat mencakup semua situasi yang arkeolog butuhkan. Hukum stratigrafi arkeologi Harris dibuat dengan tetap berdasarkan hukum geologi tetapi dengan modifikasi untuk tujuan arkeologi.

Ada empat prinsip utama stratigrafi digunakan oleh para arkeolog, yaitu: Balme dan Paterson 2006, 100-101)

a. Hukum Superposisi (law of superposition), menyebutkan bahwa asalkan belum ada gangguan berikutnya, lapisan yang lebih dalam pada stratigrafi adalah yang lebih tua daripada yang diatasnya.

b. Hukum Asosiasi (law of association), menyatakan bahwa asalkan suatu lapisan stratigrafi belum terganggu sehingga bahan didalamnya masih sama dan terkait satu sama lain. Namun, karena beberapa lapisan stratigrafi dapat merupakan periode waktu yang jauh lebih besar daripada yang lain maka kegunaan hukum ini menjadi lebih bervariasi.

c. Hukum Deposisi Mendatar (law of horizontal deposition) menyatakan bahwa setiap lapisan stratigrafi akan cenderung ke arah horizontal. Namun demikian, bentuk lapisan stratigrafi terdiri dari bahan budaya belum tentu horisontal melainkan akan ditentukan oleh aktivitas yang menyusunnya.

d. Hukum Kontinyuitas Keaslian (law of original continuity) bahwa deposit alami akan berakhir di tepi yang menipis. Jadi jika tepi lapisan stratigrafi tidak menipis maka lapisan aslinya telah hancur.

Setelah mengetahui bentuk deposit yang ada, maka arkeolog akan mencoba untuk menafsirkan urutan dari lapisan stratigrafi tersebut. Pada fakta di lapangan, sebagian besar stratigrafi di situs arkeologi telah terganggu, baik dari faktor alam maupun budaya. Gangguangangguan yang sering ditemukan adalah tergerus, dicampur, atau terdeposisi pada lokasi lain, dan kadang-kadang memotong lapisan yang mungkin memiliki bahan dan juga rentang usia yang berbeda. Ketika deposisi terjadi pada sedimen yang tererosi, telah terhapus permukaannya, atau yang belum ada deposisi untuk beberapa waktu, batas antara sedimen lama dan baru menjadi tidak selaras.Gangguan juga mungkin terjadi melalui proses kimia seperti pencucian. Menyusut dan meluasnya sedimen yang disebabkan oleh retensi air atau pembekuan sedimen memungkinkan data arkeologi untuk tertransformasi, sehingga mereka tidak lagi dalam posisi semula. Gangguan lain berasal dari proses biologi yang disebabkan oleh hewan 
atau tumbuhan. Oleh karena itu, penempatan berbagai lapisan stratigrafi dan fitur gangguan ke dalam urutan kronologis mereka melibatkan penggunaan hukum stratigrafi dan kronologi waktu serta proses dengan pengendapan sedimen di lokasi situs (Balme dan Paterson 2006, 97-116).

Lokasi penelitian di Situs Loyang Ujung Karang di Takengon, Kabupaten Aceh Tengah, Provinsi Nanggroe Aceh Darussalam. Lingkup data yang digunakan yaitu hasil ekskavasi pada lokasi tersebut tahun 2010, 2011, dan 2012. Model penalaran yang digunakan yaitu penalaran induktif dengan pendekatan arkeologi lingkungan dan jenis penelitian deskriptif-eksplanatif. Data yang digunakan adalah data arkeologi berupa lapisan stratigrafi dan data arkeologinya. Data yang didapatkan dari ekskavasi digambarkan secara verbal sehingga diperoleh gambaran tentang data arkeologi, dalam kerangka bentuk, ruang, dan hubungan antar keduanya.. Data arkeologis ini dianalisis dengan metode analisis stratigrafi menggunakan ilmu geologi sehingga diketahui proses terbentuknya lapisan stratigrafi tersebut, transformasi secara alamiah(natural transform) atau karena campur tangan manusia(cultural transform). Analisis dilakukan dengan metode analisis stratigrafi Edward Harris, dengan kodifikasi masingmasing lapisan, interval dan jejak gangguannya secara vertikal dan horizontal. Kodifikasi lapisan berdasarkan urutan pembukaan kotak ekskavasi dengan urutan dari lapisan atas ke bawah. Setelah kodifikasi lapisan, dilakukan analisis dengan memperhatikan fenomena yang terjadi di setiap lapisan pada masing-masing kotak ekskavasi dan asosiasinya/hubungannyadengan data arkeologi tentang rangka manusia. Tahap akhir adalah intepretasi data dengan menganalisis hubungan antarrangka manusia (kronologi) dan posisi/letaknyadengan lapisan stratigrafi tanah.

\section{HASIL DAN PEMBAHASAN}

Situs Loyang (Gua) Ujung Karang terletak di pinggir Danau Lut Tawar, Aceh Tengah merupakan salah satu situs gua yang sedang intesif diteliti oleh Balai Arkeologi Medan sejak tahun 2010. Situs ini berada dalam wilayah administratif Dusun Blok, Kampong Jongok Meulem, Kecamatan Kebayakan. Secara astronomis situs ini terletak pada koordinat $4^{\circ} 38^{\prime} 43.5^{\prime \prime} \mathrm{LU}$ dan $96^{\circ} 51^{\prime} 20.5^{\prime \prime}$ BT. Situs ini berada pada lereng bawah sebuah bukit dan berada lima meter dari bagian dasar lembah dengan arah hadap ke selatan. $\left(200^{\circ}\right)$, yaitu ke arah danau. Gua ini memiliki dimensi $7 \mathrm{~m} \times 10 \mathrm{~m}$. Lantai gua kering dan datar dan agak meninggi di bagian barat dengan sirkulasi udara

Tabel 1. Hasil analisis pertanggalan radiokarbon di gua prasejarah di Aceh Tengah

\begin{tabular}{|c|c|c|c|c|}
\hline \multirow{3}{*}{ SITUS } & $\begin{array}{c}\text { KEDALAMAN } \\
\text { DARI MUKA TANAH } \\
(\mathbf{c m})\end{array}$ & JENIS SAMPEL & $\begin{array}{c}\text { HASIL } \\
\text { PERTANGGALAN } \\
\text { (BP*) }\end{array}$ & $\begin{array}{c}\text { BABAKAN } \\
\text { BUDAYA }\end{array}$ \\
\hline \multirow{3}{*}{$\begin{array}{c}\text { Loyang } \\
\text { Mendale }\end{array}$} & $70-80$ & Abu pembakaran & $7400 \pm 140$ & Mesolitik \\
\cline { 2 - 5 } & 130 & Tulang & $5040 \pm 130$ & Mesolitik \\
\cline { 2 - 5 } & $40-50$ & Arang & $3580 \pm 100$ & Neolitik \\
\cline { 2 - 5 } & 20 & $\begin{array}{c}\text { Tulang dan abu } \\
\text { Pembakaran }\end{array}$ & $1900 \pm 110$ & Neolitik \\
\cline { 2 - 5 } & 20 & Tulang & $1870 \pm 170$ & Neolitik \\
\cline { 2 - 5 } & 10 & Abu pembakaran & $1740 \pm 100$ & Neolitik \\
\hline $\begin{array}{c}\text { Loyang } \\
\text { Ujung } \\
\text { Karang }\end{array}$ & $70-80$ & Tulang & $4400 \pm 120$ & Neolitik \\
\cline { 2 - 5 } & $30-40$ & Tulang & $2590 \pm 120$ & Neolitik \\
\hline
\end{tabular}

Sumber: Wiradnyana dan Setiawan 2011; dimodifikasi oleh Taufiqurrahman Setiawan 2013

Catatan: *) BP = Before Presentdan pertanggalannya belum dikalibrasi(uncalibrate) 
yang sangat baik. Di bagian depan mulut gua terdapat bongkahan batu yang merupakan runtuhan atap. Data yang ditemukan cukup kompleks dari 奕@ () masa neolitik dan proto-histori. Data signifikan yang didapatkan adalah adanya tiga rangka manusia yang masih intact (belum tertranformasi)dan lima rangka manusia lainnya yang ditemukan dalam lima kondisi yang berbeda. Dari hasil pertanggalan radiokarbon telah yang dilakukan didapatkan angka pertanggalan 4400 \pm 120 BP (belum dikalibrasi) (Wiradnyana dan Setiawan 2011, 107○ 111)

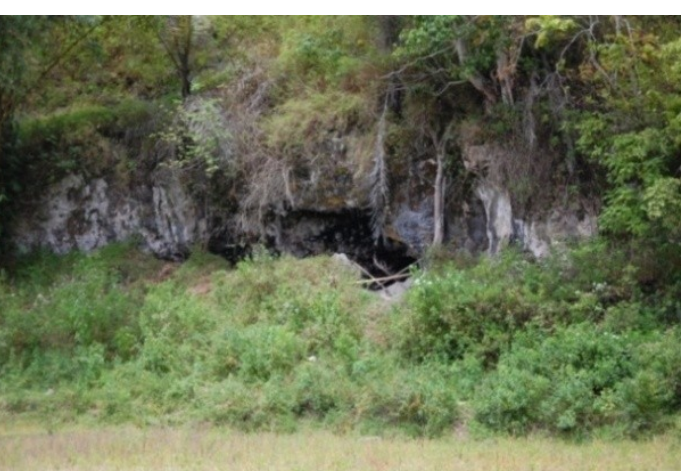

Gambar 1. Situs Loyang Ujung Karang (Dok. Balai Arkeologi Medan 2011)

Pada situs ini telah dilakukan pembukaan enam kotak ekskavasi yaitu kotak S1T1, S1T2, S1T3, S2T2, S2T3, dan U1T1. Dari kelima kotak ekskavasi tersebut telah didapatkan data berupa lima rangka manusia, fragmen gerabah, artefak batu, fragmen anyaman rotan, absklat daun, fragmen keramik, fragmen tulang binatang, dan juga sisa pembakaran (Wiradnyana dan Setiawan, 2012)Dari kelima rangka manusia tersebut, analisis baru dilakukan pada satu rangka manusia saja, yaitu rangka manusia I (selanjutnya disebut dengan R.I) yang ditemukan di kotak S2T2 yang ditemukan pada tahun 2009. Empat rangka manusia lainnya yang ditemukan pada tahun 2011 dan 2012 belum dianalisis lebih lanjut.

Pada penelitian di dua situs gua Loyang Mendale dan Loyang Ujung Karang di Aceh Tengah didapatkan data hasil pertanggalan radiokarbon seperti pada tabel 1. Berdasarkan tabel 1 diketahui bahwa lokasi di sekitar Danau Lut Tawar telah dihuni dari periode mesolitik pada $7400 \pm 140 \mathrm{BP}$. Hal tersebut didapatkan dari hasil radiokarbon yang diambil dari Situs Loyang Mendale. Untuk Situs Loyang Ujung Karang pertanggalan tertuanya adalah $4400+120 \mathrm{BP}$ dan berada pada periode neolitik. Penentuan periode tersebut didasari oleh adanya temuan fragmen gerabah yang merupakan salah satu penanda utama dari periode neolitik. Pertanggalan radiokarbon termuda adalah $1740+100$ BP. Data tersebut berasal dari Situs Loyang Mendale yang berjarak 1,3 km sebelah barat Loyang Ujung Karang. Dengan belum ditemukannya data pertanggalan lainnya, maka data pertanggalan tersebut digunakan sebagai batas kronologi termuda Situs Loyang Mendale. Hal tersebut dilakukan dengan memperhatikan kesamaan data arkeologi yang ditemukan pada kedua situs tersebut.

\section{Analisis Stratigrafi Ekskavasi Tahun 2010}

Di Situs Loyang Ujung Karang, kotak ekskavasi yang dibuka pertama pada tahun 2010 adalah Kotak S2T2. Ekskavasi dilakukan dengan sitem grid 2 x $2 \mathrm{~m}^{2}$ dengan teknik spit interval $10 \mathrm{~cm}$ mulai dari spit 1. Tujuan pembukaan kotak ekskavasi ini adalah untuk mengetahui pemanfaatan ruangan gua pada bagian depan. Pada awalnya, ekskavasi dilakukan pada kuadran baratlaut. Ketika ditemukan femur dan tulang lutut (patella) di bagian sudut tenggara, kotak ekskavasi kemudian diperluas dengan membuka dua kuadran di bagian timur. Pada kotak ekskavasi yang berukuran $1 \times 1 \mathrm{~m}^{2}$ ini ditemukan rangka manusia pada kedalaman $60 \mathrm{~cm}$ dari permukaan gua, yang kemudian diberi kode R.I. Kondisi rangka masih relatif utuh, sebagian besar anatomi tubuhnya masih dapat identifikasi dan masih intact. Posisi individu dimakamkan terlentang dengan kepala di bagian timur, kedua kakinya terlipat ke arah kanan dan berada di 
bagian barat. Kedua tangannya relatif lurus ke bawah dengan telapak tangan berada disamping badan. Tulang tangan kanan individu ini menyatu dengan tulang-tulang kaki kanan. Bekal kubur yang menyertai adalah dua buah artefak batu, mata panah dan bakal beliung, yang diletakkan di sebelah utara tangan kanan dan di atas kepala si mati. Dari analisis yang dilakukan diketahui bahwa rangka R.I ini berjenis kelamin perempuan dengan usia di atas 21 tahun, ras Mongoloid, dan tinggi 150$160 \mathrm{~cm}$. Sistem penguburan yang digunakan adalah penguburan primer dengan posisi terlentang terlipat pada bagian kaki (partial flexed burial). Selain bekal kubur tersebut, temuan lainnya adalah fragmen keramik biru putih pada lapisan atas dan beberapa fragmen tulang binatang (Setiawan 2009, 179194)

Pada lokasi gua ini terdapat delapan lapisan stratigrafi dengan klasifikasi deposisi alamiah tiga lapisan yaitu lapisan 1, 16, dan 21 dan lima deposisi budaya yaitu lapisan $7,10,11$, 14, dan 23 (lihat gambar 2). Jika analisa lapisan tersebut menggunakan hukum superposisi, maka lapisan yang paling awal adalah lapisan 21, yaitu lapisan tanah putih keabu-abuan dengan berstruktur kompak tekstur lanau. Lapisan tanah ini terbentuk secara alamiah karena adanya aktivitas air yang menggenang pada lokasi tersebut dalam waktu yang cukup lama, yaitu $4400 \pm 120$ BP sampai ke $2590 \pm 120$ BP. Lapisan ini kemudian dipotong oleh tiga lapisan yaitu lapisan 7, 10, dan 23.

Lapisan-lapisan tersebut terbentuk karena faktor campur tangan manusia. Lapisan 23 merupakan yang memotong lapisan 21 paling awal. Lapisan ini terbentuk karena aktivitas penguburan rangka manusia R.I. Tanah hasil pembuatan lubang kubur tersebut dibuang ke arah selatan. Setelah lubang kubur tersebut terbentuk, si mati dimasukkan ke dalamnya beserta bekal

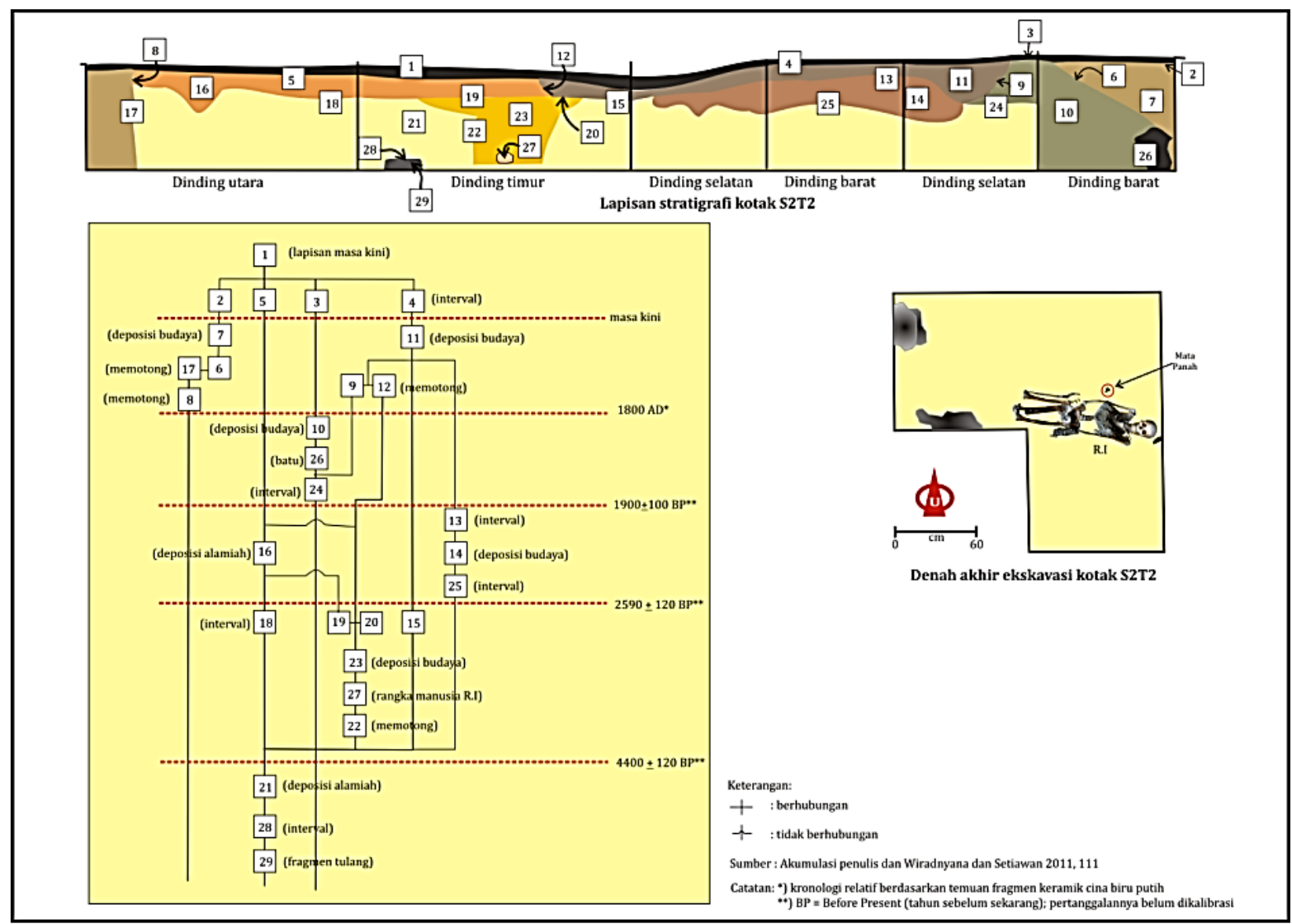

Gambar 2. Lapisan stratigrafi di kotak S2T2, diagram hasil analisis stratigrafi dan denah kotak pada akhir ekskavasi pada tahun 2010

(Gambar oleh Pesta Siahaan 2010, modifikasi oleh Taufiqurrahman Setiawan 2013) 
kuburnya dan kemudian ditutup dengan tanah hasil galiannya. Lapisan 14 yang memiliki struktur dan tekstur yang hampir mirip dengan lapisan pengisi 栾@ lubang kubur memberikan asumsi kuat mengenai hal tersebut. Lapisan 10 merupakan lapisan kedua yang memotong lapisan 21. Lapisan ini berhubungan dengan aktivitas yang dilakukan pada masa berikutnya dan pada masa selanjutnya juga dipotong oleh lapisan 7 yang tepat berada di bagian atasnya. Selain memotong lapisan 10 dan 21, lapisan 7 juga memotong lapisan 16.

Lapisan 16 ini merupakan lapisan berwarna hitam berstruktur kompak bergumpal tekstur pasir kasar dan terdeposisi secara alamiah pada bagian dalam gua. Lapisan ini terdeposisi pada periode antara $2590 \pm 120$ BP sampai $1900 \pm 100$ BP. Lapisan ini kemudian terganggu oleh aktivitas pemanfaatan lokasi gua pada masa selanjutnya. Lapisan ini dipotong oleh dua lapisan, yaitu lapisan 7 dan 10 .

Berdasarkan hasil analisis stratigrafi terlihat bahwa rangka manusia R.I berada pada kronologi waktu $2590 \pm 120$ BP. Rangka R.I ini dimakamkan dengan menggunakan lubang kubur sedalam $50 \mathrm{~cm}$ dan kemudian ditutup kembali dengan tanah hasil galian lubang kuburnya. Pada saat melakukan pembuatan lubang kubur ini tanah dikumpulkan pada bagian selatan dari lubang kuburnya. Hal itu dibuktikan adanya bekas aktivitas yang mengganggu lapisan 21 pada yang kemudian terisi oleh lapisan 14 yaitu lapisan abu-abu kehitaman berstruktur lepas tekstur pasir halus lanauan.

Ekskavasi pada tahun 2010 ini berakhir pada kedalaman $80 \mathrm{~cm}$ atau spit 8 karena keterbatasan waktu penelitian. Pada bagian dinding timur kotak ini masih ditemukan fragmen tulang yang sebagian berada pada bagian kotak S2T3. Untuk itu, pada penelitian selanjutnya masih diperlukan pendalaman kotak S2T2 dan membuka kotak S2T3 untuk mengetahui konteks dari temuan fragmen tulang yang berada pada dinding timur S2T2.

\section{Analisis Stratigrafi Ekskavasi tahun 2011}

Pada tahun 2011, penelitian lebih mendalam di situs yang sama dilanjutkan kembali dengan melanjutkan eksakavasi pada satu kuadran, baratdaya, yang belum dibuka di kotak S2T2. Selain itu, untuk mengetahui lebih lanjut tentang temuan fragmen tulang yang berada pada dinding S2T2, serta mengetahui pemanfaatan ruang gua maka dilakukan pembukaan kotak baru yaitu kotak S2T3. Sistem ekskavasi yang digunakan tetap menggunakan grid $2 \times 2 m^{2}$ dan teknik spit dengan kedalaman $10 \mathrm{~cm}$ pada setiap spitnya. Untuk memudahkan dalam pengukuran kedalaman kotak maka datum point yang digunakan untuk kedua kotak yang baru tersebut sama seperti kotak S2T2.

Pada kedua kotak (lihat gambar 3) ini diperoleh data yang relatif mirip dengan kotak S2T2, yaitu fragmen tulang manusia, fragmen tulang binatang, dan juga fragmen keramik pada lapisan atas. Pada kotak S2T3 lapisan stratigrafi tidak jauh berbeda dengan lapisan pada kotak S2T2 namun belum banyak terjadi gangguan. Lapisan tanahnya masih memperlihatkan kondisi yang masih utuh, belum banyak terganggu terutama pada bagian utara dan timur. Pada bagian timur kotak S2T3 yang berhimpit dengan bagian dinding gua lapisan membuat pengamatan terhadap lapisan stratigrafi menjadi kurang baik. Oleh karena itu, pengamatan hanya dilakukan pada dua dinding yaitu utara dan selatan. Secara horizontal, pada spit 6 ditemukan ada fitur lubang kubur yang telah terlihat pada dinding kotak S2T2 pada penelitian sebelumnya. Bentuk lubang kubur yang dibuat tidak berbentuk kotak tetapi elips memanjang timur-barat. Secara umum, lapisan-lapisan tanah ini terdeposisi karena faktor alam. Pengaruh aktivitas manusia tidak terlihat pada lapisan stratigrafinya. Pada kotak ini ditemukan fragmen tulang yang kemudian dijadikan bahan sampel pertanggalan radiokarbon yang bertarikh $2590 \pm 120$ BP (belum dikalibrasi). 
Pada ekskavasi kotak S2T3 ini ditemukan dua lapisan stratigrafi baru yaitu lapisan 33 dan 36. Lapisan 33 merupakan lapisan yang berada di atas lapisan 21. Pada lapisan ini ditemukan konsentrasi fragmen tulang (32) yang berada pada bagian sudut tenggara kotak ekskavasi ini. Fragmen tulang itu kemudian dijadikan sampel pertanggalan radiokarbon dan menghasilkan pertanggalan absolut $2590 \pm 120$ BP. Lapisan berikutnya yang ditemukan adalah lapisan 36 yang berada pada bagian timur gua dan berhimpit dengan dinding gua. Lapisan ini berwarna abu-abu kecoklatan dengan struktur kompak dan tekstur pasir halus lanauan.

Ketika ekskavasi dilanjutkan pada kotak ekskavasi ini ditemukan fragmen tulang yang berada tepat di atas lapisan stratigrafi baru yaitu lapisan 37 dengan warna coklat tua berstruktur lepas tekstur pasir sedang sampai pasir kasar. Temuan tulang tersebut berada tepat pada bagian atas beberapa fragmen gerabah. Fragmen tulang teridentifikasi sebagai tulang paha (femur) dan tulang kering(tibia dan fibula) manusia. Temuan tersebut berkonteks dengan temuan fragmen-fragmen tulang manusia yang sudah tidak utuh pada bagian utara kotak ini. Fragmen tulang tersebut kemudian dijadikan sampel untuk pertanggalan radiokarbon.
Berdasarkan pengujian di Laboratorium Geologi Bandung didapatkan hasil $4400 \pm 120$ BP (belum dikalibrasi).

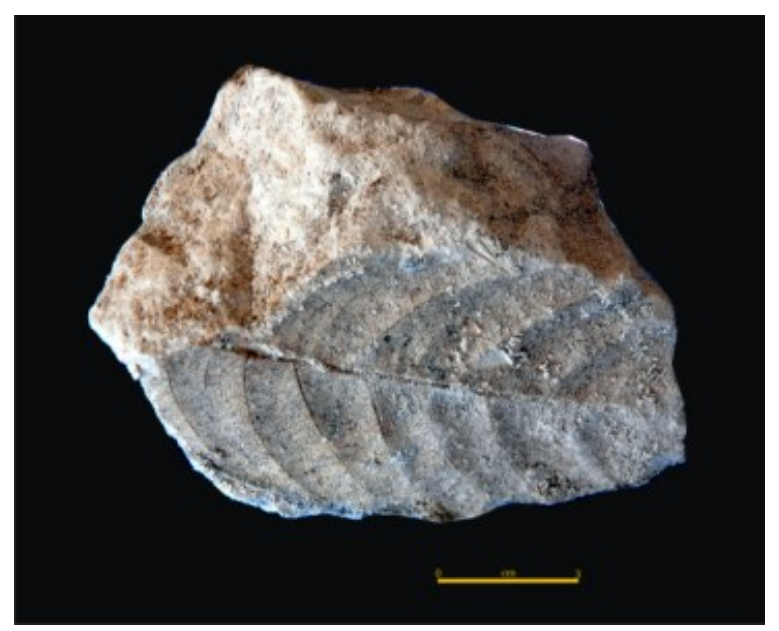

Gambar 4. Absklat (cetakan) daun

(Dok. Balai Arkeologi Medan 2011)

Temuan lain yang ditemukan pada kotak S2T3 adalah temuan fragmen absklat/cetakan daun dan fragmen anyaman rotan (39). Temuan tersebut berada pada satu lapisan dengan temuan fragmen tulang yang ditemukan di sebelah timurnya. Temuan tersebut memiliki kesamaan dengan temuan sejenis di Gua Niah Serawak, Malaysia bagian timur. Pada situs tersebut ditemukan data mengenai daun dan tikar atau keranjang yang berfungsi pada upaya penguburan. Dalam beberapa kasus mayat dibungkus
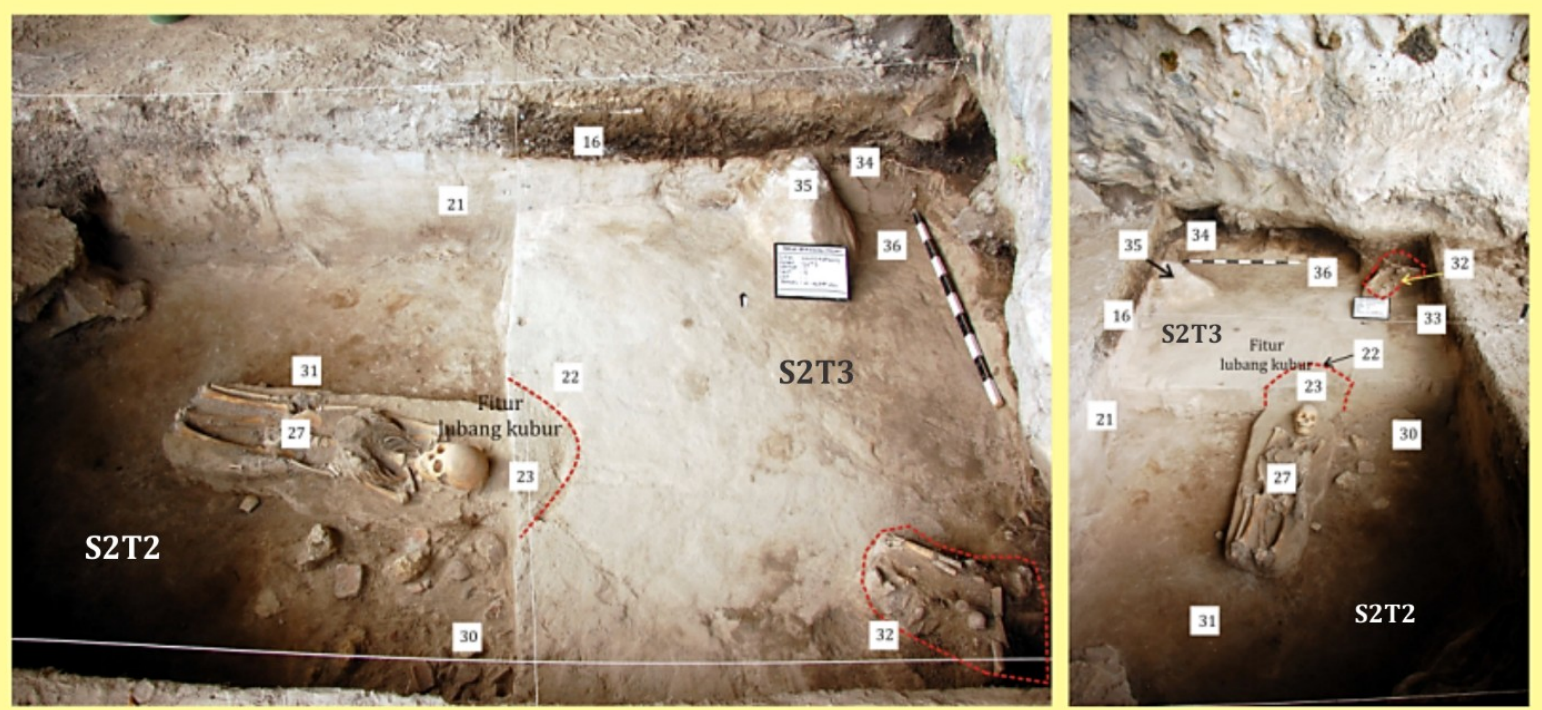

Gambar 3. Fitur lubang kubur (22) dan kodifikasi lapisan yang ditemukan pada S2T3

(Dok. Balai Arkeologi Medan 2011, modifikasi oleh Taufiqurrahman Setiawan 2013) 
dengan tikar pandan sebelum ditempatkan dalam wadah. Sebagian dari mayat ada yang dibakar dan ditempatkan dalam keranjang. Temuan 亲 $($ ) tersebut bertarikh sekitar 5000 BP dan 3000 BP (Bellwood 2000, 245).Berdasarkan hal itu, terdapat kemungkinan bahwa kedua temuan tersebut merupakan bagian dari prosesi penguburan rangka R.II karena berada pada satu lapisan stratigrafi.

Sejalan dengan pengerjaan ekskavasi pada kotak S2T3, pada kotak S2T2 juga dilakukan ekskavasi lanjutan. Hasil ekskavasi dari bagian tersebut diperoleh data sebaran gerabah di selatan temuan rangka manusia R.I. Fragmen gerabah (30) tersebut berada pada bagian atas lapisan stratigrafi coklat tua berstruktur lepas tekstur pasir sedang sampai pasir kasar. Berdasarkan pengamatan pada lapisan stratigrafinya, sebaran fragmen gerabah tersebut tidak berada pada satu lapisan dengan rangka manusia R.I walaupun pada lokasi yang berdekatan. Oleh karena itu, sebaran fragmen gerabah tersebut tidak berada pada satu masa dengan rangka R.I, melainkan pada masa yang lebih tua.

Kotak ekskavasi ini berakhir pada spit 9 dengan kondisi kotak rata pada lapisan 31 yaitu lapisan tanah coklat tua dengan struktur lepas tekstur pasir sedang ke kasar. Pada lapisan ini masih ditemukan fragmen gerabah dan juga fragmen tulang. Namun karena ruang ruang yang dapat dieksakavasi semakin sedikit maka ekskavasi pada kotak ini sementara dihentikan. Oleh karena itu, ekskavasi dilanjutkan membuka kotak S1T2.

Untuk mengetahui lebih lanjut mengenai pemanfaatan ruang gua yang lain maka dilakukan ekskavasi pada kotak ekskavasi S1T2 yang berada di sebelah utara dari kotak S2T2. Ekskavasi pada kotak ini mendapatkan satu buah tengkorak (cranium) manusia (54) dan fragmen tulang lengan (humerus) (48) pada posisi berdiri di bagian sudut tenggara.

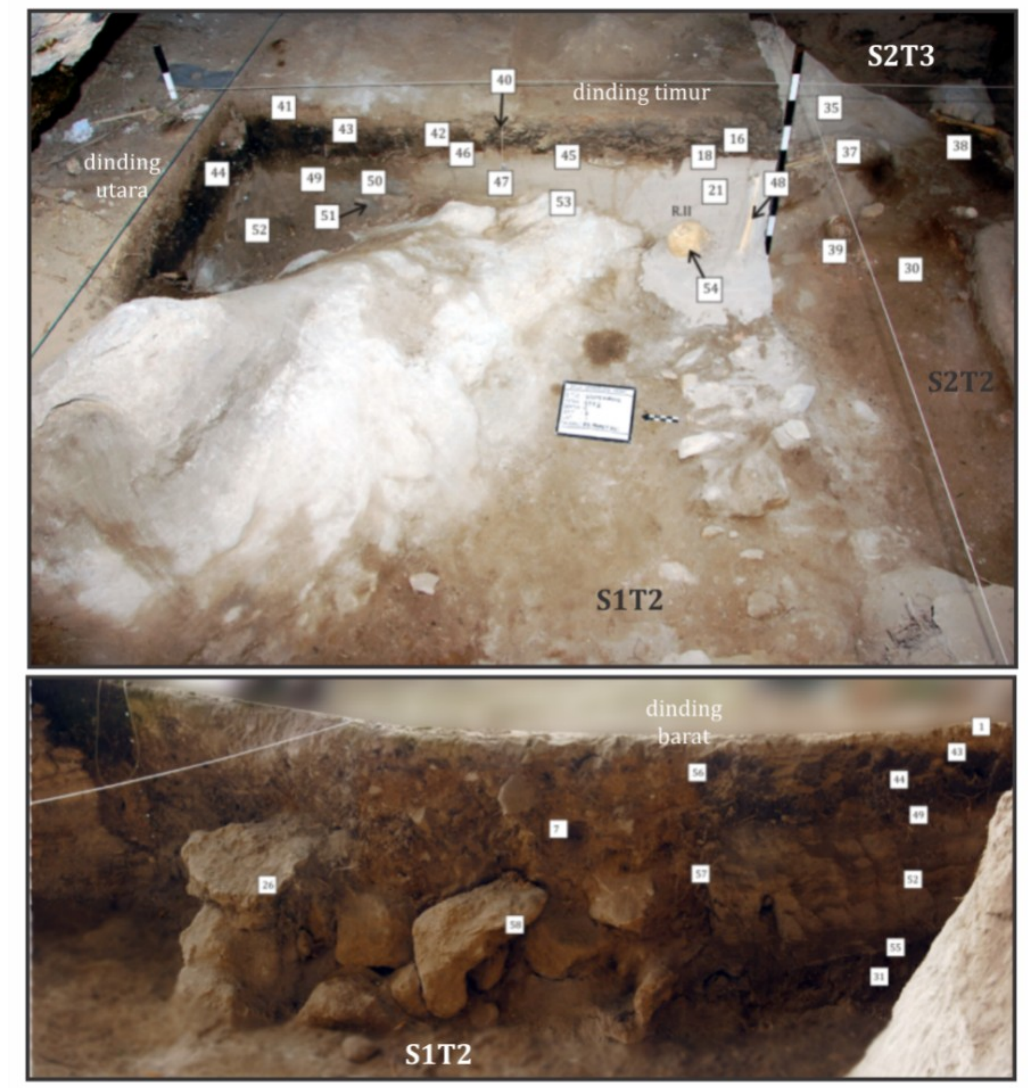

Gambar 6. Kodifikasi stratigrafi dinding timur dan barat kotak S1T2

(Dok. Balai Arkeologi Medan 2011; modifikasi oleh Taufiqurrahman Setiawan 2013) 


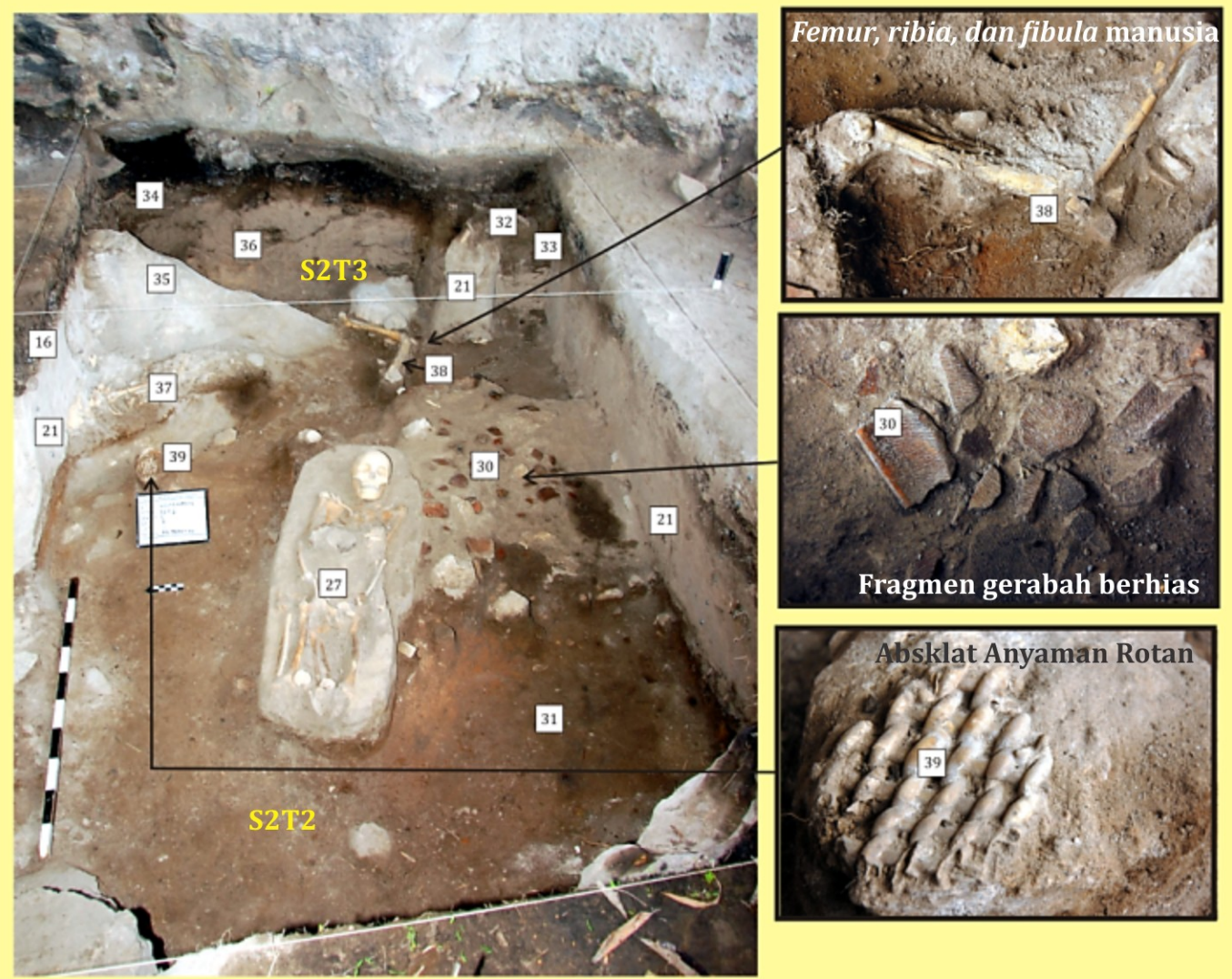

Gambar 5. Foto akhir ekskavasi kotak S2T2 dan S2T3 dan kodifikasi analisis stratigrafinya (Dok. Balai Arkeologi Medan 2011, modifikasi oleh Taufiqurrahman Setiawan 2013)

Hasil pengamatan pada lapisan stratigrafi pada bagian dinding timur memperlihatkan bahwa tengkorak dan fragmen tulang lengan tersebut bersatu dengan lapisan 21, lapisan stratigrafi abu-abu berstruktur kompak dengan tekstur lanau. Hal ini menunjukkan bahwa temuan tersebut terdeposisi karena proses pembentukan lapisan tersebut. Data tersebut memberikan gambaran bahwa dua temuan tersebut telah ada lebih dulu sebelum lapisan ini terbentuk dan kemudian tertranformasi karena proses deposisi lapisan 21. Jadi, dapat diketahui bahwa masa rangka ini adalah semasa dengan lapisan yang berada di bawah dari lapisan nomor 21, yaitu lapisan nomor 13.

Pengamatan stratigrafi pada kotak ini hanya dapat dilakukan pada dinding timur dan dinding barat saja. Pada dinding utara sebagian besar dinding tertutup oleh batuan dasar gua (bedrock). Berdasarkan pengamatan tersebut terlihat adanya sepuluh lapisan stratigrafi, yaitu lapisan 1, 7, 16, 21,31,
42, 44, 47, 51, dan 52 yang terdiri atas lima deposisi alamiah, yaitu lapisan 1 , $16,21,31$, dan 52, dan lima deposisi budaya. Lapisan 42 yang berada pada bagian utara merupakan lapisan yang tersisipi oleh lapisan 44 yang merupakan lapisan tanah hasil aktivitas pembakaran. Buktinya didukung oleh residu arang yang menempel pada bagian dinding di atasnya. Pada dinding timur ini juga terlihat adanya lapisan 47 yang menyerupai lapisan lubang kubur yang juga memotong lapisan 21 . Lapisan ini kemudian terpotong oleh lapisan 42 dan infiltrasi lapisan 52 yang bertekstur pasir sedang ke kasar. Kemungkinan lapisan ini merupakan lubang kubur, namun tidak merupakan bagian dari temuan rangka manusia R.II.

Pada bagian barat, stratigrafi yang didapatkan semakin memperkuat asumsi bahwa lapisan 7 merupakan lapisan yang memotong lapisan 16 dan 21 serta merupakan hasil aktivitas manusia pada periode yang lebih dekat dengan masa kini. Hal itu semakin 
diperkuat dengan adanya temuan fragmen batu (58) yang sengaja dibuat dan kemungkinan bagian dari peti kubur. Untuk mengetahui lebih lanjut berkenaan dengan temuan tengkorak dan fragmen tulang pada kotak S1T2 maka perlu dibuka satu kotak ekskavasi lagi yaitu S1T3. Selain itu, tujuan pembukaan kotak ini juga untuk mengetahui adanya konsentrasi fragmen tulang yang berada pada dinding utara kotak S2T3. Oleh karena keterbatasan waktu penelitian maka koatak ekskavasi ini hanya dibuka $1 \mathrm{~m} x$ $1 \mathrm{~m}$ pada kuadran baratdaya.

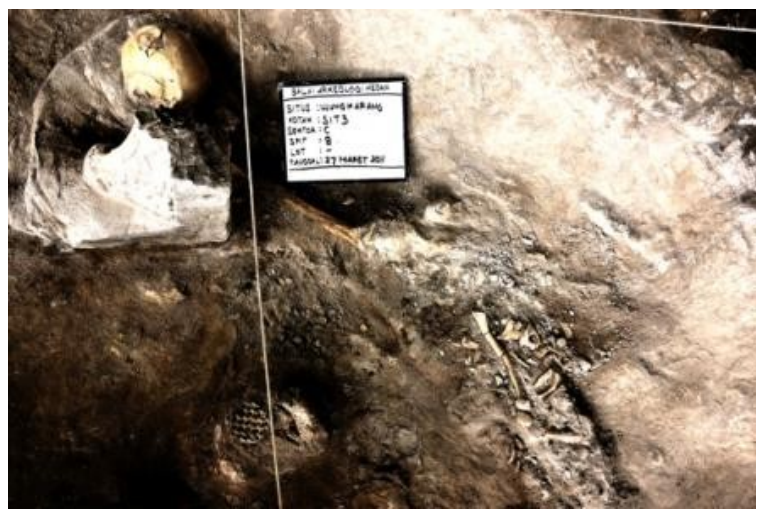

Gambar 7.Rangka manusia R.II

(Dok. Balai Arkeologi Medan 2011)

Berdasarkan hasil ekskavasi didapatkan adanya temuan rangka manusia yang telah tertransformasi dan tidak lengkap strukturnya. Temuan rangka manusia tersebut menempel pada bagian batuan dasar yang memanjang dari sudut baratlaut kotak S1T2 dan bagian utara S2T3. Dengan melihat temuan rangka manusia R.II tersebut tampak bahwa rangka manusia ini telah terdeposisi oleh faktor alamiah pada saat terbentuknya lapisan 21 . Adanya temuan anyaman rotan dan juga absklat daun mengindikasikan bahwa ketiga temuan tersebut mempunyai hubungan. Hal tersebut kemungkinan merupakan bagian dari tatacara penguburan yang dilakukan sama seperti di Gua Niah, Serawak (Bellwood 2000)
Analisis Stratigrafi Ekskavasi Tahun 2012

Pada ekskavasi tahun 2012, ekskavasi dilakukan pada dua kotak ekskavasi, yaitu kotak S1T3 dan S1T1. Tujuan pembukaan kedua kotak ekskavasi ini adalah untuk mengetahui pemanfaatan ruang gua. Sistem ekskavasi tetap menggunakan sistem grid dengan interval spit $10 \mathrm{~cm}$. Datum point tetap disamakan dengan kotak S2T2 untuk memudahkan batasan data yang didapatkan.

Pada ekskavasi sebelumnya, telah ditemukan adanya lapisan stratigrafi yang menyerupai lubang kubur seperti pada kotak S2T2. Untuk melihat lebih lanjut berkenaan dengan data tersebut maka dilakukan pembukaan kotak S1T3 yang berada pada bagian utara dari temuan rangka manusia R.I. Pada ekskavasi tersebut ditemukan adanya konsentrasi bongkah batu yang berhimpit dengan batuan dasar gua. Lapisan di sebelah utara konsentrasi batu tersebut adalah lapisan 57 dengan warna coklat muda berstruktur lepas tekstur pasir sedang. Pada lapisan ini ditemukan data arkeologi berupa fragmen gerabah, fragmen keramik, serta fragmen tulang (58). Pada saat pendalaman kotak ini ditemukan adanya jejak bekas aktivitas menggali tanah untuk membuat lubang yang memotong lapisan 61. Konsentrasi batu yang ditemukan semakin banyak dan membentuk sebuah pola mengumpul timur-barat. Saat konsentrasi batuan tersebut mulai diangkat satu-persatu didapatkan satu buah artefak batu berbahan basaltik yang kemungkinan merupakan alat untuk menggali lubang kubur tersebut. Selain itu, ditemukan juga batu-batu yang mungkin berfungsi sebagai tutup lubang kubur. Setelah seluruh bagian batu dapat terangkat ditemukan dua buah rangka manusia R.III dan R.IV yang dimakamkan pada lokasi tersebut pada satu liang lahat. Sistem penguburan yang digunakan adalah penguburan primer dengan posisi terlentang, dilipat, dan memeluk batu dan selanjutnya di tutup dengan batu. Hal itu dibuktikan dengan posisi. 


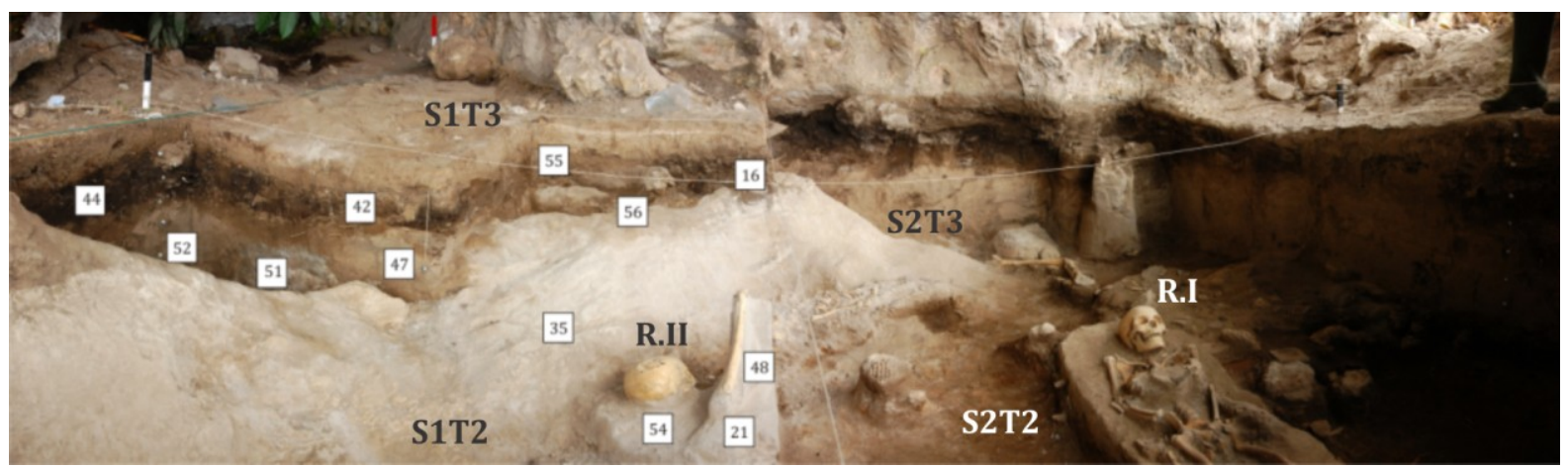

Gambar 8. Kodifikasi lapisan stratigrafi pada kotak S1T3

(Dok. Balai Arkeologi Medan 2012)
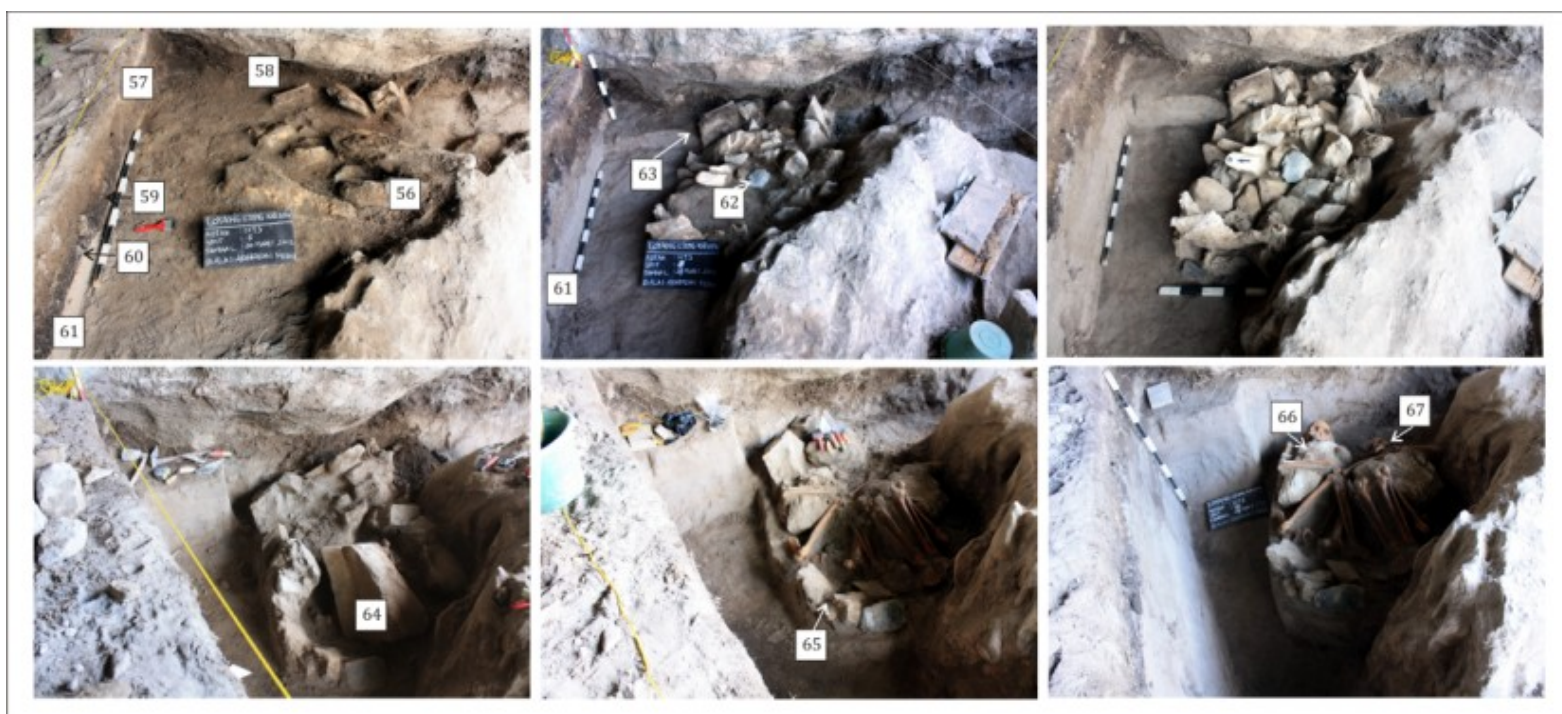

Gambar 9. Kronologi ekskavasi dan kodifikasi stratigrafi kotak S1T3

(Dok. Balai Arkeologi Medan 2012, modifikasi oleh Taufiqurrahman Setiawan 2013)

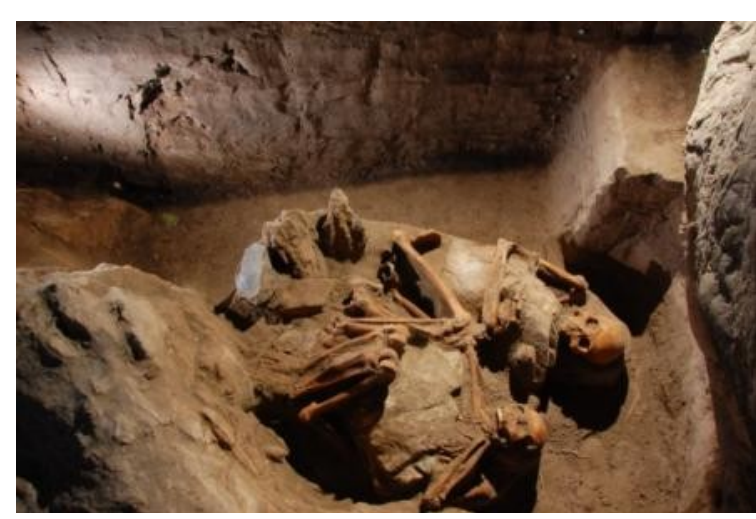

Gambar 10. Rangka Manusia R.III dan R.IV (Dok. Balai Arkeologi Medan 2012)

masing-masing tulang rangka masih pada posisi anatomisnya (intact)

Kedua rangka manusia ini R.III (67) dan R.IV (66) yang ditemukan pada kedalaman $80 \mathrm{~cm}$ ini kemungkinan salah satunya merupakan bekal kubur yang sengaja dikubur hidup-hidup untuk menemani si mati. Asumsi ini masih membutuhkan penelitian lebih lanjut dari ahli paleoantropologi forensik. Walaupun demikian, secara makroskopis kedua rangka ini dapat teridentifikasi sebagai dua individu dewasa dan berjenis kelamin laki-laki. Kedua hal tersebut teridentifikasi dari tengkorak yang lebih menunjukkan ciri tersebut dan pada tulang pahanya. Tulang pipi pada kedua rangka manusia ini cenderung mempunyai lekukan tegas dengan rahang yang besar seperti yang dimiliki laki-laki.

Pada ekskavasi tahun 2012 ini juga dibuka satu kotak lagi yaitu S1T1 dengan tujuan mengetahui pemanfaatan ruang gua pada bagian tengah dan 
mengetahui lanjut tentang adanya batu yang telah dibentuk seperti bagian peti kubur. Pada kotak ekskavasi ini ditemukan fragmen tulang, fragmen (2) gerabah, satu tengkorak, konsentrasi tulang manusia pada bagian dinding utara. Oleh karena itu, kotak ekskavasi kemudian dilebarkan dengan menambah kotak ekskavasi U1T1 dengan ukuran 1 × 0,5 $\mathrm{m}^{2}$ memanjang timur-barat.

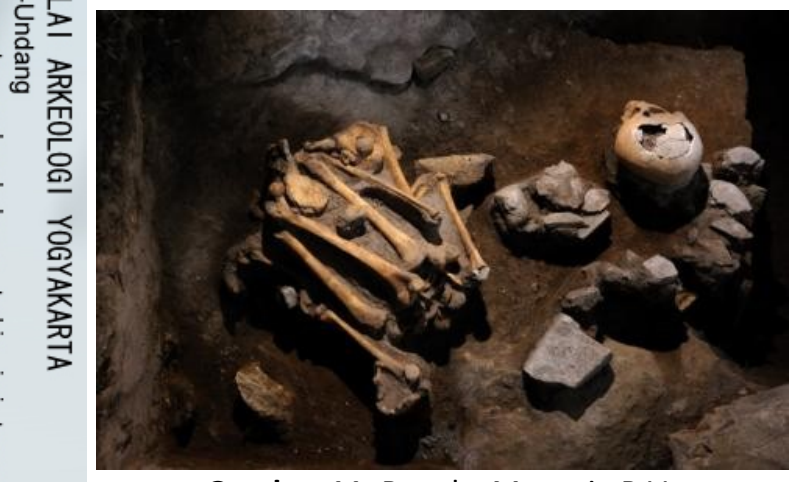

Gambar 11. Rangka Manusia R.V

(Dok. Balai Arkeologi Medan 2012)

Hasil ekstensi kotak tersebut didapatkan data konsentrasi rangka manusia R.V dengan tulang tengkorak tersebut terpisah dari bagian tulang lainnya. Temuan lainnya adalah data berkenaan dengan penguburan dengan wadah peti kubur batu. Hal itu terlihat dari beberapa batu pipih dan panjang (68) seperti papan yang ditemukan telah dikerjakan. Temuan tersebut menimbulkan asumsi bahwa tulang-

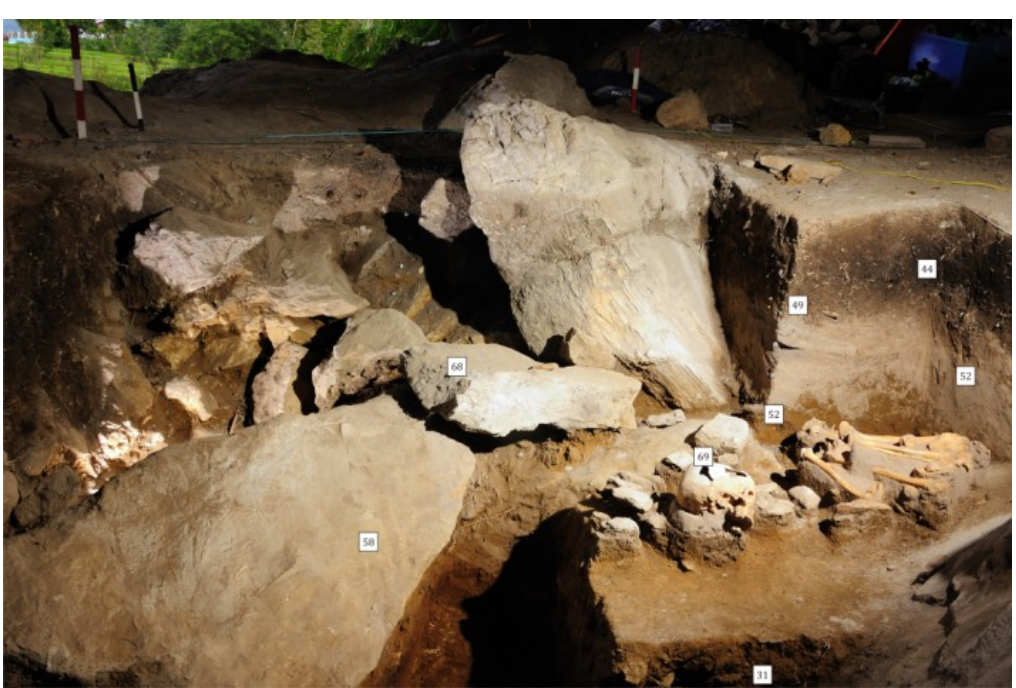

Gambar 12. Kodifikasi lapisan stratigrafi kotak S1T1 dan U1T1

(Dok. Balai Arkeologi Medan 2012, modifikasi oleh Taufiqurrahman Setiawan 2013) tulang tersebut telah mengalami proses penguburan untuk kedua kalinya. Konsentrasi tulang yang relatif rapi dengan arah yang hampir sama mengindikasikan hal tersebut.

Analisis pada lapisan stratigrafi dinding utara memberikan gambaran tentang posisi dari temuan rangka manusia R.V tersebut. Temuan rangka tersebut berada pada lapisan 52 yang merupakan lapisan yang terdeposisi secara alamiah. Lapisan ini memiliki kesamaan struktur dengan lapisan 21 tetapi memiliki warna yang berbeda dan tekstur yang lebih kasar. Lapisan ini membungkus fragmen tulang rangka R.V tanpa adanya fitur lubang kubur seperti pada rangka R.I, R.III, dan R.IV. Hal ini memberikan gambaran bahwa lapisan ini terbentuk belakangan setelah tulang-tulang tersebut diletakkan pada lokasi tersebut.

Pada dinding kotak bagian selatan terlihat bahwa lapisan 10 merupakan lapisan yang memotong miring ke arah timur lapisan 31 yang berada dibawahnya. Pada lapisan ini banyak ditemukan batu-batu runtuhan atap gua terlihat pada bagian dinding barat kotak ekskavasi ini. Beberapa diantaranya terdapat batu yang mungkin sengaja dibentuk karena menunjukkan adanya bekas pengerjaan dan yang mungkin dimanfaatkan bagian dari penguburan. 


\section{Kronologi Hunian Di Situs Loyang Ujung Karang}

Jika dilihat lima rangka manusia yang ditemukan di Situs Loyang Ujung Karang secara horisontal akan menghasilkan asumsi bahwa rangka tersebut berasal dari satu periode. Asumsi ini didukung dengan terdeposisinya lokasi yang relatif sama kedalamannya. Namun, dengan tambahan data stratigrafi, diketahui bahwa kelima rangka manusia tersebut berasal dari tiga periode yang berbeda.

Hasil analisis lapisan stratigrafi menunjukkan bahwa pada situs tersebut telah dihuni sebelum 4400+120 BP dengan bukti data arkeologi fragmen gerabah, rangka manusia, abklat daun dan anyaman rotan yang ditemukan pada kotak S2T3. Dengan adanya data berupa gerabah tersebut merupakan penunjuk masa neolitik. Lokasi ini kemudian ditinggalkan hingga $2590 \pm 120$ BP karena permukaan gua tergenang air bersamaan dengan naiknya permukaan Danau Laut Tawar. Hal ini ditunjukkan dengan adanya lapisan lanau yang merupakan lapisan yang hanya dapat terdeposisi pada kondisi air tenang tanpa arus. Selain itu, pada lapisan ini juga tidak ditemukan data arkeologis yang semakin menunjukkan bahwa pada lapisan ini tidak ada aktivitas budaya.

Pada lapisan lanau tersebut terdapat dua temuan rangka manusia yaitu R.II dan R.V yang menyatu dan tidak ditemukan fitur lubang kubur di sekitar tulangnya. Hal ini memberikan gambaran bahwa rangka manusia tersebut telah ada sebelum lapisan lanau tersebut terbentuk. Rangka R.II mempunyai konsentrasi tulang yang menyebar merupakan hasil akumulasi proses yang menggeser rangka tersebut dari posisi asal dimana rangka tersebut diletakkan. Berbeda dengan rangka R.V, temuan ini menunjukkan konsentrasi tulang yang cenderung terpola dan rapi
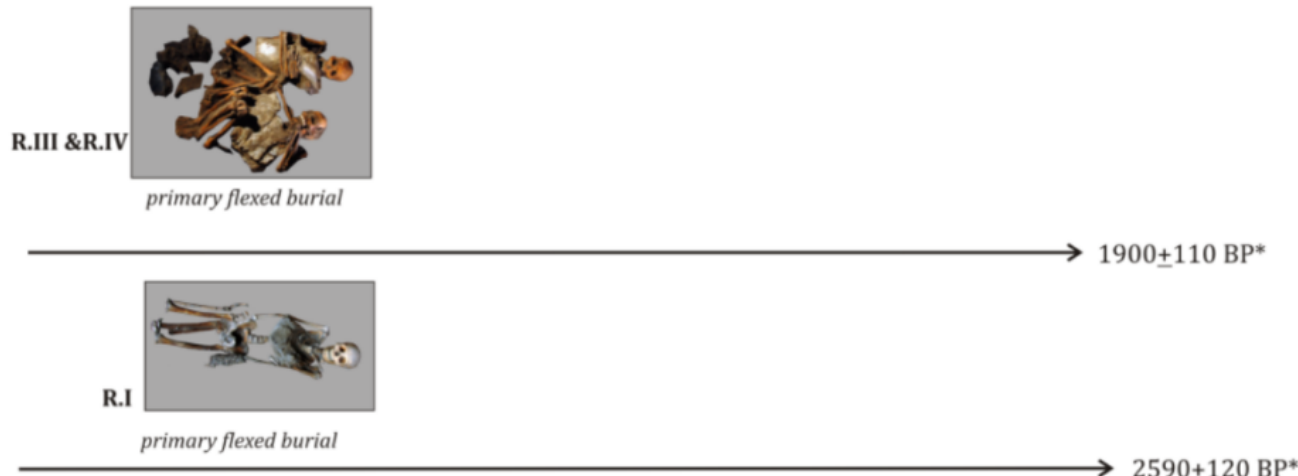

$4400+120 \mathrm{BP} *$

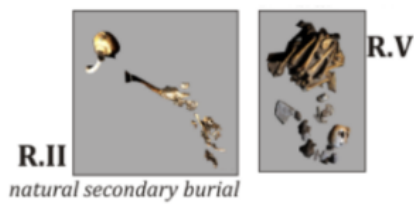

Sumber : Akumulasi penulis dan Wiradnyana dan Setiawan 2011,11

Catatan: *) BP = Before Present(tahun sebelum sekarang)

Gambar 13. Kronologi hunian dan manusia pendukungnya di Loyang Ujung Karang

(Gambar oleh Taufiqurrahman Setiawan 2013) 
dan keberadaan tengkorak yang berada di bagian selatan konsetrasi tulang tubuhnya dapat terjadi karena proses transformasi alamiah ketika air 栾@ menggenang pada lokasi tersebut. Situs ini baru kemudian digunakan antara 2590+120 BP hingga 1900+100 BP dengan bukti penguburan manusia R.I yang ditemukan di kotak S2T2. Fitur lubang kubur yang ditelihat pada bagian dinding timur kotak ini menunjukkan pemanfaatan lokasi gua setelah permukaan danau turun dan lantai gua mengering. Pemanfaatan lokasi pada masa berikutnya belum didapatkan pertanggalan radiokarbonnya tetapi secara berdasarkan temuan fragmen keramik cina yang berasal dari Dinasti Ming (abad XIV sampai XVII) yang ditemukan pertanggalan relatifnya sekitar $1800 \mathrm{AD}$ (200 BP). Pada lapisan tersebut terdapat temuan rangka manusia manusia R.III dan R.IV yang ditemukan di bagian paling dalam gua. Sistem penguburan primer dengan menggunakan lubang kubur dan diberikan dinding batu serta ditutup dengan batu yang membentuk seperti peti memberikan perlakuan khusus terhadap si mati. Jika salah satu rangka yang ada dalam satu lubang kubur tersebut ternyata dijadikan bekal kubur dan ikut dimakamkan hidup-hidup bersama si mati, semakin memperkuat asumsi bahwa si mati mempunyai status sosial yang tinggi dalam kelompoknya.

Dari penjelasan tersebut di atas dapat disimpulkan bahwa gua tersebut setidaknya telah dimanfaatkan sebanyak tiga periode hunian dengan penghuni yang mungkin berbeda-beda sejak 4280 BP hingga 200 BP. Periode penghunian tersebut berawal dari periode neolitik yang ditunjukkan dengan adanya temuan fragmen gerabah, hingga sampai ke periode Islam yang ditunjukkan dengan adanya temuan fragmen keramik dari Dinasti Ming.

Rangka manusia yang ditemukan di Situs Loyang Ujung Karang berasal dari tiga periode yang berbeda walaupun lokasi deposisi kelima rangka tersebut hampir sama. Rangka manusia R.II dan R.V merupakan penghuni awal lokasi ini, kemudian situs ini ditinggalkan karena permukaan air Danau Lut Tawar menggenangi ruangan gua, sehingga menjadi tidak layak dihuni. Setelah kondisi permukaan air danau mulai turun dan permukaan lantainya mengering, gua ini kembali dimanfaatkan sebagai lokasi penguburan rangka manusia R.I. Lokasi tersebut kemudian ditinggalkan kembali dan baru dihuni kembali oleh kelompok yang lain. Hal ini dibuktikan dengan adanya temuan rangka manusia R.III dan R.IV.

\section{PENUTUP}

Berdasarkan analisis yang telah dilakukan didapatkan hasil bahwa Situs Loyang Ujung Karang mempunyai kronologi hunian yang dikelompokkan dalam tiga periode penghunian yaitu (1) sebelum $4400 \pm 120 \mathrm{BP}$, (2) $2590 \pm 120$ BP sampai $1900 \pm 110 \mathrm{BP}$, dan (3) 200BP sampai masā kini.

\section{UCAPAN TERIMA KASIH}

Penulis mengucapkan terimakasih kepada Drs. Ketut Wiradnyana, M.Si yang telah mengizinkan penulis menggunakan data penelitian Situs Loyang Ujung Karang, dan memberikan masukan dan dukungan sehingga tulisan ini dapat terselesaikan. 


\section{DAFTAR PUSTAKA}

Balme, Jane dan Alistair Paterson. 2006. "Stratigrafi" dalam Jane Balme and Alistair Paterson (ed). Archaeology in Practice: A Student Guide to Archaeological Analysis. Australia: Blackwell Publishing. HIm. 97 - 116.

Bellwood, Peter. 2000. Prasejarah Kepulauan Indo-Malaysia. Jakarta: PT. Gramedia Pustaka Utama.

Harris, Edward. 1989. Principles of Archaeological Stratigraphy. London: Academic Press Limited.

Nurani, Indah Asikin. 1995. "Pola Permukiman Gua-gua di Kaki Gunung Watangan: Suatu Hipotesis Permukiman Gua Kawasan Timur Jawa" dalam Manusia dalam Ruang: Studi Kawasan dalam Arkeologi. Berkala Arkeologi Tahun XV-Edisi Khusus. Yogyakarta: Balai Arkeologi Yogyakarta. HIm. 78 - 88.

Setiawan, Taufiqurrahman. 2009. "Sistem Penguburan Terlipat Takengon, Tambahan Data Baru Penguburan Dalam Gua di Indonesia" dalam Sangkhakala No. XIII Volume 27. Medan: Balai Arkeologi Medan. HIm. 179 - 194

Simanjuntak, Truman, 1998. "Budaya Awal Holosen di Gunung Sewu" dalam Berkala Arkeologi Th. XIX Edisi No. 1/Mei. Yogyakarta : Balai Arkeologi Yogyakarta. HIm. 1 $-20$

Simanjuntak, Truman (ed). 2002. Gunung Sewu in Prehistoric Times. Yogyakarta: Gadjah Mada Univesity Press.

Sugiyanto, Bambang. 2009. "Pola Pemanfaatan Gua-Gua Hunian Prasejarah di Kalimantan Selatan dan Timur" dalam Naditira Widya, Volume 3 Nomor 2, Oktober 2009. Banjarmasin: Balai Arkeologi Banjarmasin. HIm. 133 - 144.

Wiradnyana, Ketut. 2011. Prasejarah Sumatera Bagian Utara: Kontribusi pada Kebudayaan Kini. Jakarta: Yayasan Pustaka Obor Indonesia

Wiradnyana, Ketut dan Taufiqurahman Setiawan. 2011. Gayo Merangkai Identitas. Jakarta: Yayasan Obor Indonesia.

2012. "Ekskavasi Gua-gua di Kabupaten Aceh Tengah, Provinsi Nanggroe Aceh Darussalam". Laporan Penelitian Arkeologi. Medan: Balai Arkeologi Medan.

Yondri, Lutfi. 2010. "Batu Kendan dan Manusia Prasejarah di Tepian Danau Bandung Purba" dalam Naditira Widya, Volume 4 Nomor 1, April 2010. Banjarmasin: Balai Arkeologi Banjarmasin. HIm. 1 - 10.

Laman:

www.kompas.com. Kerangka Purba di Gua Harimau: Para Penghuni Awal Sumatera. Editor: Tri Wahono (diakses tanggal 11 Januari 2011 pukul 15.00 WIB). 


\section{Lampiran:}

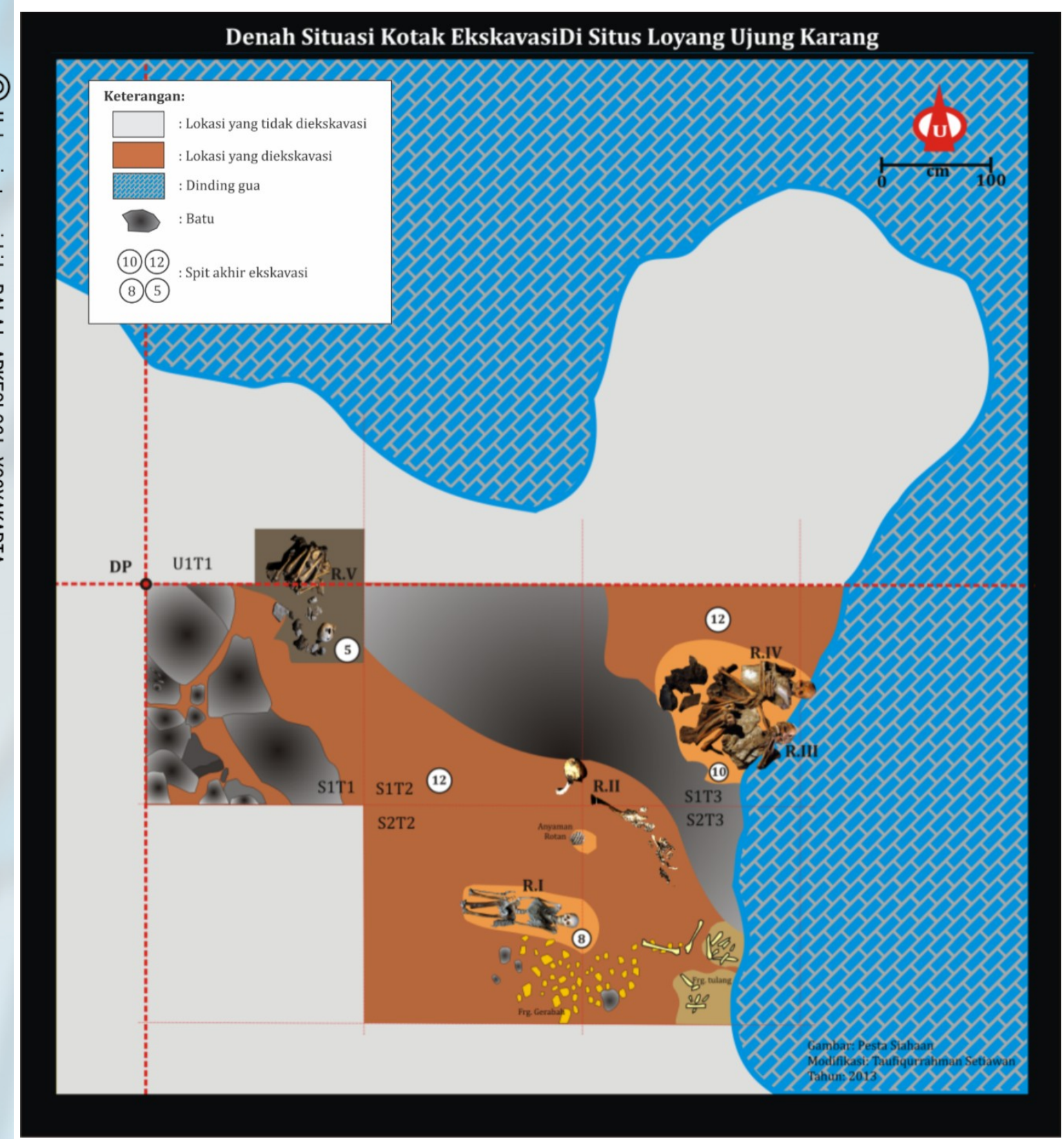

Gambar 14.Denah situasi hasil ekskavasi Situs Loyang Ujung Karang pada tahun 2012

(Gambar oleh Pesta Siahaan, modifikasi oleh Taufiqurrahman Setiawan 2013) 